\title{
Artist autonomy in a digital era: The case of Nine Inch Nails
}

\author{
STEVEN C. BROWN[1] \\ Glasgow Caledonian University
}

\begin{abstract}
A 2009 presentation by Michael Masnick (CEO and founder of insight company Floor64) entitled 'How Trent Reznor and Nine Inch Nails represent the Future of the Music Business' brought the success of the business models employed by Reznor in distributing Nine Inch Nails' music into the spotlight. The present review provides a comprehensive timeline of the band circa 2005-2010, evaluating the success of the distribution methods employed in accordance with Masnick's (2009) proposed business model of connecting with fans and providing them with a reason to buy. The model is conceptualised in the wider context in which Reznor's distribution methods take place (including a brief consideration of Radiohead's much cited pay-what-youwant model), addressing the perceived gaps in the model by exploring the involvement of musical preferences; age and consumer purchasing behavior and fan worship. Implications are discussed concerning the applicability of the model for new and emerging bands.
\end{abstract}

Submitted 2012 January 17; accepted 2012 June 8.

KEYWORDS: music distribution, marketing, piracy, Internet, musical preferences

\section{INTRODUCTORY REMARKS}

THIS paper is divided into three discrete, yet complementary sub-sections. The first section is a case study of Trent Reznor and Nine Inch Nails circa 2005-2010, specific to aspects relative to commercial success. Masnick's (2009) business model (see below) is referred to prominently throughout. The second section aims to expand upon the business model, discussing relevant academic literature from various disciplines, with Masnick's (2009) model argued as being overly simplified. Conclusions and recommendations based on the findings of both sections follow in section three.

\section{'HOW TRENT REZNOR AND NINE INCH NAILS REPRESENT THE FUTURE OF THE MUSIC BUSINESS'}

Michael Masnick (2009) is President and CEO of Floor64, a company who aim to develop new ways for companies to connect and share ideas in order to progress. Masnick is also the CEO and founder of Techdirt, a blog focusing on technology issues and technology related news. Additionally, Masnick contributes to BusinessWeek's Business Exchange.

He delivered a presentation at the 2009 Midem conference bringing together influential figures in the music industry worldwide. The 15-minute presentation was entitled 'How Trent Reznor and Nine Inch Nails Represent the Future of the Music Business' [2] and maps out how Reznor successfully connects with fans, whilst also providing them with a reason to buy. Connecting with fans is principally accomplished by capitalizing on the practical benefits of distributing and promoting music using the Internet, whilst providing fans with a reason to buy is achieved largely by adding value to physical products. The model will be referred to prominently throughout the remainder of the article, where Figure 1, overleaf, summarises its simplicity. 


\section{Connect with fans + Reason to buy $=$\begin{tabular}{|l}
\hline \\
Success
\end{tabular}}

Figure 1. Masnick’s (2009) business model.

\section{NOTHING CAN STOP ME NOW: A TRENT REZNOR CASE STUDY[3]}

\section{I take you where you want to go: Who is Trent Reznor?}

Nine Inch Nails is the principal creative project of multi-instrumentalist Trent Reznor[4], who while frequently working with others (including employing a rotating line-up of musicians when performing live) remains wholly responsible for its direction. Since announcing a hiatus in performing live, Reznor has composed the Academy Award-winning soundtrack to The SOCIAL NETWORK and the US version of The GIRL with the DRAGON TATTOO, with frequent collaborator Atticus Ross, who along with Reznor's wife Mariqueen Maandig, form Reznor's latest musical outfit How to Destroy Angels.

Nine Inch Nails is an industrial rock project, with Reznor's pop sensibilities and accomplished piano playing lending songs such as 'CLOSER' and 'The PERFECT DRUG' enough commercial appeal to penetrate mainstream audiences. Themes of isolation, belongingness and self-hatred characterise many of the lyrics, perhaps best captured in 1992's 'GAVE UP': “After everything I've done I hate myself for what I've become”, with suitably dark music videos solidifying Reznor's image as 'the dark lord of doom' (Rees, 1999). Ferocious in a live setting, Nine Inch Nails is a genuine live spectacle with dazzling visuals often accompanying energetic performances. A marked gap between major releases was once commonplace, peaking at a 6-year gap between 1999's The FRAGILE and 2005's WITH TEETH. Since then, the sheer volume of Nine Inch Nails activity (particularly the touring schedule) is only rivalled by that of its online fan community.

While celebrated for various awards and accolades over his career, Reznor has long been known for various corporate entanglements and outspoken disputes against the music industry where in May 2007, for example, he spoke out against the pricing and distribution of the Nine Inch Nails album YEAR ZERO in Australia. Attacking Universal Music Group, the parent company of his then record label Interscope, he stated: 'As a reward for being a true fan you get ripped off' (Bruno, 2007). Reznor would go on to urge fans to illegally download his songs at a live performance in Sydney in 2007 as a way of drawing attention to those involved that what they are doing is not right; that they are 'ripping people off' (Moses, 2007). In essence, the label was accused of exploiting fans perceived willingness to pay anything for physical copies of Nine Inch Nails albums, where a recent qualitative study identified different 'tribes' in the teenage music market including loyalists whose 'favourite artists are placed on a pedestal and CD's are bought on blind faith without reviewing them first' (Nutall, Arnold, Carless, Crockford, Finnamore, Frazier, \& Hill, 2011, p. 158). This label effectively typifies the stereotypical obsessive Nine Inch Nails fan, in this instance essentially being punished for their loyalty rather than rewarded.

The move came at a memorable crossroads in the modern history of digital music distribution, just weeks ahead of Radiohead's pay-what-you-want model when distributing their $7^{\text {th }}$ album $\operatorname{In} R A I N B O W S$, a model which Reznor himself built upon when distributing releases subsequent to YEAR ZERO (after his contract ended with label Interscope). Radiohead's official website registered over 3 million visits during the first 60 days after the release of In RAINBOWS, with prices ranging from the 45p handling fee to £99.99 (Kim, Natter \& Spann, 2009) with approximately one third choosing to pay nothing and the remaining two thirds paying an average of $£ 4$. The net revenue to the band thus came in at around $£ 2.67$ pounds on average - far more than the band's share would have been under their normal business agreement (Green, 2008). Harbi, Grolleau, and Bekir (in press) explain how such innovative strategies are likely to redefine value across the music industry.

The success of Radiohead's distribution method attracted much attention in the press, aiding its public relations and marketing advantage (Dubber, 2011) and was met with both praise and criticism from other musicians. Sigur Ros front man Jonsi Birgisson commented that: 'Bands get so little money from every CD they sell anyway. Doing it like this, if they only get a few pounds, they might actually get more than before' (Colothan, 2007). In more recent years however, artists have reflected on the assumed negative impact of the model. The Cure's Robert Smith in February 2009 stated: 
The Radiohead experiment of paying what you want - I disagreed violently with that. You can't allow other people to put a price on what you do, otherwise you don't consider what you do to have any value at all, and that's nonsense. If I put a value on my music and no one's prepared to pay that, then more fool me, but the idea that the value is created by the consumer is an idiot plan, it can't work.

(Leanord, 2009).

The profit generated by ignoring traditional intermediaries is likely to have got Reznor's attention, who would essentially adapt this method to one which has spawned attention in the world of business, popular media and more recently, academia (Harbi et al., in press; Ogden, Ogden, \& Long, 2011; Wikstrom, 2009). A detailed timeline of Nine Inch Nails circa 2005-2010 is outlined below, highlighting relevant examples of connecting with fans and offering them a reason to buy, akin to Masnick's (2009) model.

\section{Just a glimpse: Nine Inch Nails 2005-2010}

Nine Inch Nails' return to the spotlight in 2005 was an exciting time for fans. It was also a notable example of using the Internet to communicate with fans. While the official website (www.nin.com) existed years prior to 2005, it wasn't until this time that Internet usage had become as ubiquitous as it is today, or indeed as user-friendly, with Reznor maximising its potential early on in the critical period of activity in the world of Nine Inch Nails which took place between 2005 and 2010.

In 2005, the source files for the hit single 'The HAND that FEEDS' were released allowing fans to create their own remixes; a move which let fans engage and interact with the music in a new, innovative way, enabled by capitalising on the technology available. This also allowed fans to no longer experience the music of Nine Inch Nails as merely passive consumers, but allows access to a physical product of Reznor's creative output in an intimate fashion. Ultimately, in Masnick's (2009) terminology, the move connected with fans.

An extensive online remix fan community would follow on from this move where future releases also included source files for songs in a range of formats for fans to download and remix. Most notably, Y34RZ3ROR3MIX3D (leetspeak for YEAR ZERO REMIXED) included source files for every track from the previous album, 2007's YEAR ZERO. Here, fans were provided with a reason to buy, getting more than just the songs themselves. An entire sub-section of the official Nine Inch Nails website is now committed to remixes and continues to prosper. Elsewhere on the website, hundreds of live video clips can be found which are embedded from Youtube.com, with the clips submitted by fans. Image galleries also exist in a similar vein along with various ways for fans to chat together online. Effectively, the wider Nine Inch Nails community can co-exist in creative ways, coming together using digital communications; sustaining interest in Nine Inch Nails between releases and live performances. The official website is a central hub for fans, and offers Reznor a unique medium to connect with fans and moreover, allow them to connect with each other.

To this end, a fan club was established in 2005 called The Spiral. A standard membership and premium membership were offered to fans, differing in price and benefits. Membership benefits included earlier access to live performances and access to concert pre-sale tickets where members' names were printed on tickets in an attempt to cut down on ticket scalping. This move also provides fans with tangible physical reminder of their attendance at the concert, with the inclusion of a printed name providing a far more meaningful and arguably valuable document of the concert experience and a further reason to buy a ticket. The fan club effectively took the existing online Nine Inch Nails community and legitimised it by giving it a name, offering exclusivity in the form of members only t-shirts and Nine Inch Nails e-mail accounts, for example. At this time, the seeds were sown for what would be a prolific period in the history of the band, with virtually constant touring. Curiously, Reznor would transform himself from an enigmatic and elusive character to that of a more approachable and altogether more real personality by using the various communication mediums available using the Internet to connect with fans.

\section{Just a little reminder: Nine Inch Nails 2005-2010}

In 2007, prior to the release of the epic concept-record YEAR ZERO, Reznor utilised the scope of the Internet by creating an alternate reality game which existed in tandem to the record itself; expanding upon 
the albums dystopian narrative. 'Clues' were hidden within merchandise such as on t-shirts with certain letters or numbers marked differently which would ultimately turn out to be IP addresses. These discoveries went viral, leading to websites being discovered and shared by the online community. Fans were given an additional reason to buy merchandise, lured by the appeal of being a part of an exciting Internet scavenger hunt. In both the online remix community and with the YEAR ZERO viral marketing campaign, continued involvement is likely to be as much about continued group membership amongst the Nine Inch Nails community as anything else.

Ahead of the release of YEAR ZERO, USB pens were hidden at concerts with unreleased songs officially leaking them. The YEAR ZERO CD itself turned from black to white (see Figure 2) from the heat of being played which revealed more clues leading to fans discovering new websites. Indeed, other than Nine Inch Nails' debut album PRETTY HATE MACHINE, none of the records come in conventional jewel cases. Some, including the special edition release of 2002 live album And all that COULD HAVE BEEN, for example, are presented in luxurious packaging. Later, the ultra deluxe version of the 2008 instrumental album GHOSTS I-IV would be nominated for a Grammy for best boxed set or limited edition packaging. Lush packaging in releases such as those noted above offer a genuine reason to buy music in hard copy format. The selling point of the compact disc has long been its greater audio quality, where preference for digital music today appears to stem from its greater convenience. With preference for digital music expanding, physical copies of music must offer something beyond the music itself, where the efforts of Nine Inch Nails in creating valued relics cannot be understated as a driver for successful sales.

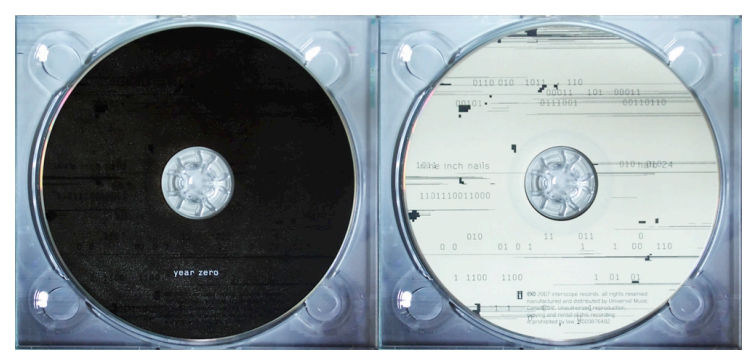

Figure 2. Year Zero CD colour change: Before and after.

GHOSTS I-IV and the subsequent release The SLIP were released in 2008 under Creative Commons license - a non-profit organisation aiming to develop more flexible copyrights. The move, with hindsight, feels like the natural progression from allowing fans access to the source files of songs, where the lines between fans as passive listeners and fans as actively being involved in the music itself is further blurred. The latter two albums were initially released digitally, with physical releases coming later. With GHOSTS I-IV, various formats were made available to fans, ranging from a free download of the first volume ( 9 of the 36 tracks) to limited edition ultra-deluxe packages priced at $\$ 300$ each. Here, Reznor connected with fans by providing them with choice, giving them with a reason to buy physical copies of the 2500 limited edition ultra-deluxe packages of GHOSTS I-IV, by hand signing them. Priced at $\$ 300$ each, and selling out in under 30 hours, an initial $\$ 750,000$ gross revenue was made on these boxed-sets for music that was also effectively being given away for free. Masnick (2009), comments that additional 'value' was added to the music itself with the inclusion of Reznor's signature.

The success of GHOSTS I-IV is compelling, given that fans could have easily downloaded it via any file-sharing service or bit-torrent service. Benenson (2009) reports that the record generated over $\$ 1.6$ million in revenue for Nine Inch Nails in the first week alone, hit number one on Billboard's Electronic Charts and was ranked the $4^{\text {th }}$ most listened to album of the year on Last.fm with over 5,000,000 scrobbles. More interestingly, GHOSTS I-IV was also ranked as the best selling mp3 album of 2009 on Amazon's mp3 store. In another way of connecting with fans, Reznor called upon creative fans to submit user-generated music videos for the songs from the album as part of a 'film festival'. In Wikstrom's (2009) words: 'The fans' reception of the Ghosts project cannot be labelled as anything but exceptional' (p. 1).

The digital copy of The SLIP (released just months after GHOSTS I-IV) was made available completely free of charge as a gift to fans in various high quality formats, another way of connecting with fans. The timing of the release, coinciding with announcing live concert performances, was argued by Masnick (2009) as purposeful. In doing so, fans could download and enjoy music and then immediately 
afterwards buy concert tickets. Indeed, the subsequent tour would ultimately sell out. Commenting on the nature of live Nine Inch Nails shows as 'complete entertainment experiences' characterised by compelling visuals for example, Nine Inch Nails live is essentially reasoned by Masnick (2009) as the ultimate form of connecting with fans; whilst providing them for a reason to buy. This argument is compelling, not least because live performance is the only form of paid-for music consumption that is increasing (Dilmperi, King, \& Dennis, 2011), despite ticket prices increasing (Holt, 2010), but because it is the main source of income for artists (Connolly \& Krueger, 2005).

In the case of Nine Inch Nails, at least in the period under scrutiny, exposure to music appears to significantly impact ticket sales; where historically live music has been used to promote sales of hard copies, and prior to the 20th century was consumed only via live performances (Dilmperi et al., 2011). This relationship now seems to have reversed, with this notion better demonstrated in lieu of the release of free samplers to fans to download featuring tracks not only by Nine Inch Nails but the other support bands on respective tours, including Jane's Addiction. This new way of connecting with fans ultimately arms them with a reason to buy concert tickets where Holt (2010) argues that artists consider recordings less a revenue stream than a publicity tool for touring. To this end, Chesbrough (2009) argues that whatever revenue Radiohead may have lost through the initial download experiment on In RAINBOWS was more than compensated for by the far greater publicity the band received, attributed as accounting for the surge in commercial sales and benefiting ticket sales for their subsequent world tour; a sentiment echoed in Harbi et al.'s (2010) consideration of Radiohead's pay-what-you-want-model as an alternative to piracy.

Tour footage was uploaded by Reznor in 2009, in HD-quality and made available as a mammoth 400GB bit-torrent download. Fans have since created their own live concert films by working collaboratively on the Internet in what is effectively the largest scale example of connecting with fans to date in the Nine Inch Nails community, grounded in the same mould as allowing fans to remix songs. In January 2010, fans began non-profit screenings all over the world. The use of bit torrent added to the speculation amongst fans that Reznor was the source of a 'leak' of a live DVD release of CLOSURE, a live concert film previously released on VHS, which appeared on bit-torrent website The Pirate Bay. Reznor stated: 'A couple of years ago around this time of year, somebody must have broken into my personal files and uploaded onto a torrent site the entire DVD of Closure[...] So that basically means that it doesn't need to come out on DVD anymore' (Cruz, 2008).

As a sought after producer (who in addition to several film credits has also produced music by the likes of Marilyn Manson and Zach De La Rocha) Reznor's latest non Nine Inch Nails producer role incorporated his innovative distribution methods. He produced alternative hip-hop act Saul Williams' 2007 record The INEVITABLE RISE and LIBERATION of NIGGY TARDUST! (which Reznor also co-wrote) and released via his official website. The first 100,000 fans were given the option to pay $\$ 5$ for a digital copy of high quality copy of mp3 or FLAC files or download the record for free, with lower quality audio files. Reznor commented on the move as an improved successor to Radiohead's pay-what-you-want model used when releasing In RAINBOWS, little over a month earlier. The relative success of Saul Williams' record where just over $18 \%$ of the 154,449 people who chose to download the album paid $\$ 5$ (Idolator, 2008) raises the issue of how successful e-commerce strategies such as those mentioned above are for lesser known acts, who cannot rely on a pre-existing fan-base.

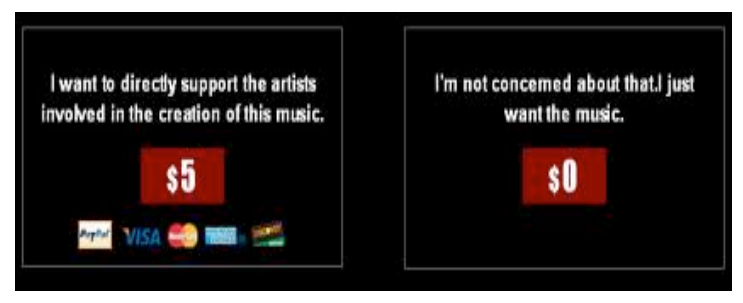

Figure 3. Saul Williams album download screenshot: Designed to induce guilt?

While appearing disheartened, Reznor comments positively on the fact that over five times as many people sought out Williams' album than the previous one and that there was no money whatsoever spent on marketing (Idolator, 2008). Here, Reznor is effectively adhering to Curien and Moreau's (2009) recommendation that record companies could accommodate piracy by making the most of its main positive feature - mass access to music at a very low cost. In discussing the increased number of people now 
familiar with Williams' music, Reznor also appears to be addressing the previously defined relationship between recorded music and live music, where recorded music essentially sells live music.

The potential for a model such as the one used with ...NIGGY TARDUST! can be inferred from research by Regner and Barria (2009), who explored the success of online music label Magnatune where customers pay what they choose, within price range of $\$ 5$ and $\$ 18-$ the recommended price is $\$ 8$. Revenue for sales is split evenly between the artist and the label, with the artists typically being relatively unknown.

Pre-purchase access allows for informed buying decisions which the authors state as 'setting it apart from conventional online music stores' (Regner et al., 2009). Data were collected over an 18 month period of all transactions where the average price paid for an album was $\$ 8.20$; significantly higher than the minimum of $\$ 5$ and higher than the recommended price of $\$ 8$. To this end, a digital market for lesser known artists such as Saul Williams may have potential. Critically, and in addition to Magnatune's offering of pre-purchase sampling of songs, $\$ 5$ is listed as a minimum price, with a recommended price of $\$ 8$. Reznor's strategy when selling ...NIGGY TARDUST! online offers far less choice, something he would remedy later on future Nine Inch Nails releases GHOSTS I-IV and The SLIP, where Masnick (2009) argues that providing choice is an effective way of connecting with fans. It is also feasible that fans may have been put off purchasing Williams' record due to the options given upon purchase, which appears to be designed to make fans feel guilty about not paying for the record. Regner (2010) observed reciprocity as a major driver of generous donations in a follow-up study, where reciprocity will be explored in further sections of this article.

\section{And in the end: Case study summary}

The case study above, reviews the endeavours of Trent Reznor in utilising the Internet to ensure the continued success of Nine Inch Nails 2005-2010, where reference is made to examples of connecting with fans and giving them a reason to buy - Masnick's (2009) proposed business model to account for his success. The business model offers a simplified view of a complicated process, involving the exchanges between fan and artist, and is likely to draw attention from other artists. Strong examples of connecting with fans and providing them with a reason to buy have been demonstrated.

The model is extremely useful, and helps factor an intricate problem down to two complementary elements, which, once identified, are likely to become salient to fans when considering the reasons for spending money on their favourite bands. Given the comparative non-success of Saul Williams' record being marketed digitally in a similar vein to that of Nine Inch Nails, it is argued that there are elements missing from the model which help account for the success enjoyed by Reznor. By citing relevant literature from various disciplines, exploring the success of other musicians and other methods for distributing music, the suitability of Masnick's (2009) model and the strategies employed by Reznor for new and emerging bands will now be explored.

\section{ANOTHER VERSION OF THE TRUTH: A CLOSER LOOK AT NINE INCH NAILS} 2005-2010

\section{Even deeper: What is missing from the model?}

Two of Masnick's (2009) considerations are explained in more detail - value and quality; merchandise and ticket sales - with two elements argued as missing from the model proposed: age-based habitual purchasing behavior and fan worship. Literature is drawn from a variety of disciplines, where the applicability of Reznor's music distribution methods for new and emerging bands is considered throughout.

\section{This machine is obsolete: Value and quality}

Recorded music no longer has a fixed value. It can be purchased in a variety of formats, streamed online as part of a subscription service or even downloaded illegally for free. It stands to reason that as a consequence of this, consumers no longer have a fixed perception of the value of music and thereby how much they are willing to pay for it. With reference to the case study of Trent Reznor above, the issue of price and value, as discussed by Masnick (2009) is prominent. So many different pricing strategies now exist that subsequent value is now largely unfixed. Arguably, the much cited pay-what-you-want model 
employed by Radiohead has contributed to this the most. The recent explosion of subscription services however, is likely to leave the largest impact on how consumers perceive the value of music, where the convenience digital goods offer is valued highly.

Bhatacharjee, Gopal and Sanders (2003) defined that participants' willingness to pay for music depended on the perceived value of music. It was also observed that lowering the price of sampling encouraged legal purchases of music and that the quality of music alone did not significantly alter willingness to purchase music, with over $90 \%$ of respondents rating compressed music quality as almost the same or very good as compared to CD quality music. As such, the authors argue that pricing models based on sound quality are unlikely to succeed. While the majority of consumers are not likely to place much emphasis on sound quality, some clearly do - and they are prepared to pay more for it. Reznors' decision to market GHOSTS I-IV in different bundles based on sound quality would have excited some fans enough that a segmented approach is indeed likely to generate increased revenue from this sub-sample of consumers. In Masnick's (2009) terms, by offering choice, you are also connecting with fans. Reznor also lowered the cost of sampling GHOSTS I-IV by making the first 9 tracks available to download for free, which as stated, encourages legal purchases of music as consumers are willing to pay more for a $\mathrm{CD}$ with a known song than for one with an unheard song (Bhatacharjee et al., 2003).

Moving from price to value, Masnick (2009) notes that Reznor's inclusion of a signature on the ultra-deluxe version of GHOSTS I-IV added value to the music in its form as a tangible product, therefore providing fans with a reason to buy. Several studies have shown that consumers who attach a higher value to a product typically tend to purchase it rather than download it illegally (Cheng, Sims, \& Teegen, 1997; Conner \& Rummelt, 1991; Gopal \& Sanders, 1998). Furthermore, added-value is one of the four strategies to encourage legal purchases of music proposed by Chiu, Lin, Lee, Nieh, and Chen (2008), in their paper on how to discourage music piracy. With the deluxe version of GHOSTS I-IV, Reznor's signature in addition to being limited to 2500 copies is likely to have contributed towards the success of the albums performance in terms of hard-copy sales. In other words, by adding value to Nine Inch Nails' music, the music was successfully sold in a traditional physical format.

Value is subjective (see Menger, 1871). The implications for this are that by adding perceived value to music in the form of making them more exclusive or collectable with deluxe packaging for example, fans will be more likely to buy them. When no difference is perceived in sound quality when ripping music from a $\mathrm{CD}$, what is the real difference between a bought $\mathrm{CD}$ and one which has been copied or even downloaded? To the casual listener, none. To some music fans, in Nutall et al.'s (2011) words techys, quality is likely to be an important factor when deciding whether or not to buy recorded music. Similarly, non-price related measures in hard copies such as liner notes etc (as argued by North and Hargreaves, 2008) are likely to discourage pursuing pirated versions of music. If this is the case, then perhaps a segmented approach to distributing music could be beneficial, where the functions or uses of music can help distinguish between different types of listener and consequently, their propensity to pay for recorded music.

To summarise, careful consideration of the physical presentation of hard copies of albums can reap benefits. With the value of music now being largely unfixed, artists can alter perceived value amongst their fanbase in creative and subtle ways where new and emerging bands could potentially improve the likelihood of profiting from recorded music by being innovative.

\section{This big broken machine: Merchandise and ticket sales}

Subscription services such as Spotify contribute towards a new culture where recorded music can be used in such a way as to generate interest in acts to see live; where merchandise and concert tickets are sold alongside the music itself. Given the notion of recorded music effectively selling live music in the Reznor case study, particularly with the tour samplers outlined earlier, any potential loss in sales from simply 'giving away' The SLIP is likely to have been more than counterbalanced from the profits from the farewell Wave Goodbye tour. The title of the tour itself and the decision to tour with Jane's Addiction is likely to have elicited a degree of nostalgia amongst veteran Nine Inch Nails fans, with the bands having performed at the inaugural Lollapalooza Festival some 20 years previously. Nostalgia sells, grounding your affinity with a band in a particular time period. This is bound to motivate concert attendance. In Masnick's (2009) terms, this would connect with fans by encouraging them to connect and be a part of a landmark in the history of their favourite artist, furthermore providing a reason to buy merchandise. The merchandise from 
touring circa YEAR ZERO with t-shirts which revealed 'hidden messages' would also have generated a lot of revenue for the same reason as above.

The implications for this are that profits gained from merchandise and ticket sales are potentially so great that music can be given away for free, without it being at a detriment to the artist financially. As Dance act David Guetta states: 'Sometimes you have to give away content - even if it isn't bringing you money. It's about building a relationship' (Forde, 2011). In practice however, an existing audience must be in place for such a strategy to work for new and emerging bands where relentless touring is no suitable alternative to profits made from recorded music. It is possible, to address Reznor's use of Creative Commons licensing to distribute GHOSTS I-IV and The SLIP, that by sidestepping traditional routes of distribution by ignoring intermediaries, that a greater profit can be generated where as Curien et al. (2009) outline, utilising the Internet provides the ability to ensure extensive access to music at very minimal expense. Once more however, the importance of an already existing audience emerges as crucial where bands such as Nine Inch Nails or Radiohead are able to adopt risky distribution methods as they are still riding the wave of commercial success throughout the 1990's; before the onset of piracy.

In summary, merchandise is a lucrative source of income for bands and can be sold both on official websites and at concerts - where intermediaries' involvement could range from little to zero. In order to motivate live concert attendance however, sampling of recorded music is necessary. As has been mentioned elsewhere, recorded music now effectively promotes live music - with recorded music potentially less of a revenue stream than live music (Holt, 2010).

\section{The collector: Age and habitual purchasing behaviour}

Returning to the comment of the likes of Nine Inch Nails still reaping the benefits of peaking commercially during the 1990's; the year 2000 emerges as a symbolic and viable marker in the modern history of music piracy. As Goldberg (2009) illustrates, in 1999, most Internet users had dial-up connections and unlimited Internet access was not yet widely available. Even if users did not pay for CDs, they would pay for the time spent connected to the Internet, downloading each song. 2000 was also the year of Radiohead's experimental fourth record KID $A$ whose innovative marketing strategy of releasing short films called 'blips' on the Internet scored by music from the album demonstrated the capacity for music and the Internet to co-exist at the turn of the millennium. The album was also famously leaked onto file-sharing giant Napster ahead of release, though it has been speculated that this ultimately facilitated legal sales through word-of-mouth.

2000 was also the year Jones published the seminal article 'Music and the Internet', where he speculates on the nature of fandom in relation to music; suggesting the affective dimensions and loyalties associated with popular music practice may find new forms of expression through use of new technologies. The Nine Inch Nails case study above, largely supports this claim, where Reznor effectively utilised the Internet to revolutionize not only music itself in the use of innovative distribution methods, but in his public presentation, where regular updates on the official website helped fill the gaps between releases maintaining fan interest in Nine Inch Nails.

The year 2000 is postulated as a viable cut-off point in explaining a timeline involving 'pre' and 'post' piracy, where it is feasible that bands emerging in the latter half are more likely to struggle to generate an income with traditional sales of recorded music. To clarify, bands who were established and successful prior to what will be referred to as the 'onset' of piracy in the year 2000, may continue to sell hard copies of music to their pre-existing fan base who are in the habit of buying their products. To argue the concept above more convincingly, the phenomenon of musical preferences must be considered.

Exploring the links between established bands and musical preferences, North and Hargreaves (1995) observed that there is a tendency for individuals to rate artists as eminent who had their first UK number one when participants were late adolescents/early adults. Their preferences were directly related to participants' ages. Building on this finding, a further study by North and Hargreaves (2002) investigated over 12,000 nominations of the greatest pop musician gathered from large-scale survey data where sales charts were used to determine the mean year in which nominated musicians achieved their first UK top 10 album. A critical period prevailed once more, found amongst late adolescence/early adulthood.

Musical preferences is a growing area of research in Music Psychology and one which helps address the links between Nine Inch Nails fans and their purchasing behaviours. It is argued that extending this age-specific finding of musical preferences in accordance with the profile of pirates as typically young (see Malin \& Flowers, 2009, for example), that bands established before 2000 can and will continue to sell 
music to fans who enjoy hard copies. New bands may struggle to sell music to new fans who are only familiar with illegal downloading.

To this end, Lee and Low (2004) found that there was a generational difference in the direction one might expect with regards to age-related purchases of hard copies of music where younger people ('Generation Y', born 1976-1991) tended to download unauthorised music more than 'Baby Boomers' (born 1946-1960). Baby boomers reported a preference for owning a CD. This is perhaps better illustrated in the findings of the aforementioned qualitative study by Nutall et al. (2011) where one female teenager commented: 'I think there's a generational difference. For older people there's a preference for CDs and records as they were the only way [for them] to access music' (p. 155). Adopting a qualitative approach, further research by McIntyre (2011) into age revealed: 'Boomer records shop-buyers and Generation Y downloaders exhibit key generational identity differences in intrinsic meanings, values and associations inherent within their differential music transactional processes' (p. 150). Furthermore, Cockrill, Sullivan, and Norbury (2011) have observed indicators of addiction amongst heavy users of mp3 technology. 80\% of these were aged 18-25 years.

To summarise, age is a crucial variable in accounting for differences in why some individuals choose to buy hard copies of music and some do not. Considering the practicalities of extending the concept of musical preferences to that of preferences for accessing and listening to music, future fans of music are likely to favour using the Internet as it grows more omnipresent to obtain music and therefore prefer mp3s and other digital formats of music. As such, bands who have emerged/emerge post-piracy should aim to address this whilst connecting with fans by offering their fans a variety of formats to purchase music.

\section{We're in this together now: Fan worship and the relationship between fan and artist}

Returning to Nutall et al.'s (2011) qualitative study exploring music consumption, the authors note that several of the teenagers interviewed described 'their affiliation to particular artists and the influence this had on their decision to legally purchase an album because they 'owe it' to the artist' (p. 156). Furthermore, Wang, Chen, Yang, and Farn (2009) have found that higher idolatry results in a higher intention to buy music. By way of example, and to link in with the aforementioned strategy of increasing perceived value, Smith (2011) remarks Radiohead's distribution strategy of eighth studio album The KING of LIMBS as emulating 'the approach of creating a lavish physical format that the most loyal fans will feel they have to own, whatever the cost'. The phenomenon is known as fan worship and in the context of encouraging legal sales of music; the relationship between fan and artist cannot be understated.

Ivaldi and O'Neill (2008) conducted a factor-analysis on the 14 reasons they discovered for admiring musical role models; defining three main reasons why adolescents' admire a role model: dedication, popular image and ability. All of these are relevant to Reznor. His dedication is perhaps best demonstrated through his studio perfectionism and subsequent lengthy gaps between releases; his popular image as 'the dark lord of doom' (Rees, 1999) formed part of the appeal throughout the 90's, best depicted in the $\mathrm{S}$ and $\mathrm{M}$ imagery of videos such as 'CLOSER' and his ability as a multi-instrumentalist married with his technical prowess in the role of producer which have defined a unique inimitable sound.

That these three factors may be partially responsible for the strong relationship between fan and artist in the case of Nine Inch Nails, is made all the more plausible in light of the findings of another qualitative study, by Saarikallio and Erkkila (2007), who explored the role of music in adolescents' mood regulation. Seven unique regulatory strategies were identified, including solace, where particular attention is paid to lyrics - often in isolation. The authors noted that participants identified with the lyrics, and felt that the songwriter had faced up to feelings, worries and experiences similar to their own, helping them to connect with the artist. Given Reznor's often dark lyrics and relatively narrow lyrical palette principally concerning themes of isolation, abandonment, loss and belongingness, it is likely the lyrics of Nine Inch Nails are a fundamental attraction to Reznor's music. His naked lyrics help form a unique relationship with adolescents in particular, with consequent influence on consumer purchasing behaviours via age-based musical preferences. Furthermore, by engaging with Reznor, fans are ultimately drawn to him on a more personal level where reciprocity is more likely to be carried out. To this end, elusive superstars such as Madonna are perhaps more likely to suffer from piracy where blogging, fanclubs with exclusive interviews etc are likely means for musicians to help create a way of allowing their fans to engage with them on a more personal level, leading to reciprocal behaviour. 
Reciprocity forms the basis of Shultz's (2006) research into jambands; defined as bands whose live sets include much improvisation and variation and who allow their fans to record their live shows, copying and distributing them freely. The phrase is befitting for Grunge veterans Pearl Jam, who have been offering fans soundboard quality recordings of their live shows since 2000. These 'unofficial bootlegs' provide fans with documents of their live concert experiences, where as Masnick (2009) stated, live music is the ultimate form of connecting with fans and providing them with a reason to buy. Exploring the success of Tori Amos' use of 'official bootlegs', Farrugia and Gobbato (2010) argue that Amos' efforts at personalising each show increases the perceived value of each recording to those who were there. Amos and Powers (2005) note for example how throughout the 2005 Beekeeper tour Amos solicited fan requests for cover songs via her website, performing at least two of her fan requests. This level of interaction helps crystallise the importance of the relationship between fan and artist in creating a successful working relationship, adhering to supply and demand traditions, and subsequently increasing the likelihood to purchase hard copies of live music documents.

Such recordings can of course be easily obtained illegally for free and many fans are likely to do so, without affecting ticket sales. Those who do pay for them are the hardcore fans who enjoy bootlegs (Naghavi \& Schulze, 2001) and circulation of their live recordings both legally and otherwise form part of the reciprocal relationship between artist and fan. In Shultz's (2006, p. 657) words 'the music industry thus needs to think in terms of building loyal communities that have reciprocal relationships with artists rather than simply moving physical products into the hands of consumers'.

To summarise, the relationship between fan and artist has been suggested as particularly crucial in generating revenue from music. Indeed, Regner (2010) identified reciprocity as a major driver for generous voluntary payments on Magnatune. Specific to Nine Inch Nails, the lyrical content of the music is suggested as likely to attract adolescents who are in turn reasoned as likely to continue to purchase music through habit; with the music perhaps serving certain needs including mood regulation. Other specific reasons why fans may idolise Reznor are proposed, with findings suggesting that fan worship plays an important role amongst fans when deciding whether or not to purchase music. Fan worship is intrinsically linked to how long a band has been active, which is why the acts mentioned continue to sell music to their fanbase. New and emerging bands cannot exploit fan worship until such time as they have an established group of fans and as such, should focus on other means to generate revenue as outlined in previous subsections above.

\section{The line begins to blur: Reciprocity in practice}

In the case of Nine Inch Nails, and returning to reciprocity, perhaps the best illustration of how important the working relationship is between artist and fan can be found in the organisation This One Is On Us, an international group of Nine Inch Nails fans who have filmed and produced a series of live concert films, with high quality audio provided by Reznor himself. The commitment to work towards a shared goal is inspirational, and indicative of their commitment to the band. Their positive mission statement, below, draws together several of the threads discussed so far, shining optimistic light on the potential future of how fans and artists will interact:

We aim to restore live music as a shared, passionate entity, and work with those who embrace new media and the realities of the Internet to build on their relationship with fans through collaboration and to create unique documents of their live events. Providing organizational, technical and financial support, we encourage fan communities to plan and execute first-rate film and audio recordings, and turn the resulting content into professional quality releases. Direct fan involvement allows us to capture the essence of a live experience, not only providing a souvenir for those that attended, but also allowing the world to live the show virtually first-hand. This One Is On Us profoundly enhances the relationship between artist and fan; a revolution emerges where the two meet

(This One is On Us, 2010). 


\section{AFTER ALL IS SAID AND DONE: CONCLUSIONS}

\section{Problems have solutions: Summary of findings}

A comprehensive review of certain aspects of Nine Inch Nails circa 2005-2010 has been outlined, including an account of ways in which the Internet was utilized to stimulate interest in both live music and recorded music; such as innovative music distribution methods. The aspects discussed can be broadly categorized using Masnick's (2009) business model which was also explored, citing relevant examples of connecting with fans and providing them with a reason to buy. Such examples were presented as largely accounting for Reznor's recent success.

In addition, reference to academic literature was presented in an attempt to address gaps in the model where such gaps are argued as accounting for a large proportion of the variance in Nine Inch Nails' fans willingness to buy the recorded music of their favourite band. North and Hargreaves (2008, p. 254) state: 'Music piracy is an economic process, but it is a psychological process also, and other factors such as a desire to be involved with the music can only be addressed by non-price related measures such as liner notes etc'. To this end, a number of additional considerations for Reznor's success have been identified including: fan worship, and the relationship between fan and artist and habitual purchasing behavior, as moderated by age.

Furthermore, it has been suggested that bands established prior to the onset of digital piracy (with 2000 postulated as a viable cut-off point), such as Nine Inch Nails, are likely to continue to sell music to pre-existing fan bases, motivated by fan worship and perhaps habit. Bands which have emerged in recent years would do well to consider the case study outlined above in detail, with suggestions for how to generate profit including:

(1) Lowering the cost of sampling music (to encourage legal sales of music)

(2) Revenue through merchandise and ticket sales (live music as a rich source of income)

(3) Increasing the perceived value of recorded music (to motivate a reason to buy)

(4) Develop a reciprocal relationship with fans (with limitless possibilities for future rewards)

The changing face of the live album was briefly considered, with discussion on new ways in which fans and artists can interact and produce economical live concert films. It is ironically the open source ethos which drives piracy which could lead to minimal reproduction values for live concert films now being zero. Furthermore, due to their collaborative creation, they may also have increased value with the future of the live album perhaps not being 'I was there', but 'We were there'.

Wikstrom (2009) argues that the creative desires of such individuals should be actively encouraged, making the assumption that: 'fans who create, remix and upload content are also the most loyal. It is also quite likely that they are the ones who spend the most on concerts, merchandise etc. (p. 8-9). Whilst technology facilitates illegal downloading of music, it can also be employed effectively to encourage loyalty to a particular group - with clear benefits. The case study above demonstrates the practical benefits of welcoming technology, exploring various avenues to engage with audiences and facilitate continued interest in a group between major releases.

\section{A wave goodbye: Recommendations}

In Masnick's (2009) terms, connecting with fans and giving them a reason to buy is a rich strategy to encourage financial reward in the music industry, and such a template should prove fruitful for other artists. Indeed, Radiohead's latest digital distribution model for The KING of LIMBS mirrors Reznor's GHOSTS I$I V$ distribution model, perhaps indicating that the strategies employed by Reznor, as outlined in the above case study, mark the peak of successful innovative digital music distribution - at present.

The case study is a potentially useful insight into an artist who is perhaps less well known than the likes of Radiohead, with Harbi et al. (2011) dedicating a whole article to analyzing the potential for Radiohead's pay-what-you-want-model as an alternative to piracy (who concluded 'yes', but not 
necessarily for all artists). Their timely and insightful article suffers from the principal shortcomings of Masnick's (2009) model, failing to address psychological principles - such as fan worship. The present article also marks the introduction of Masnick's (2009) model into academic discussion. Masnick is perhaps better known for coining the phrase the Streisand effect [5].

The case study shows that the Internet can be utilized to an artist's advantage and that building a successful relationship with fans is integral to continued mainstream success. As Forde (2011) argues, the core concern for modern artists is engaging with audiences and building a community of fans. To this end, perhaps a case study of Pearl Jam could provide useful in defining the potential for reciprocity to be perhaps the most successful anti-piracy campaign of them all, where their efforts to create an intimate reunion style atmosphere at their live shows is inspiring.

New and emerging bands are reasoned as perhaps not benefiting from the exact models employed by Reznor, but that they can learn from them all the same. In Reznor's words: 'the steps we've taken.. I think, have gotten closer to something that approaches a business model. It doesn't work for bands that nobody knows yet' (Ryan, 2009). To this end, it will be interesting to see what distribution model Reznor employs for his new band How to Destroy Angels. Regner, Barria, Pitt and Neville (2009) illustrate that different business models appear to be optimal at different stages of an artists' career. Furthermore, David (2010) references six case studies, citing different practices for bands starting out in the business, presently superstars and 'beyond that stage' (p. 154) where additionally, piracy has been shown to affect artists differently (Mortimer, Nosko \& Sorensen, 2010; Piolatto \& Schuett, 2012). Regner et al. (2009) comment: "It follows that there will not be a single answer to the question of what is the future business model for digital media" (p. 341).

Additionally, and in accordance with Masnick (2009), live music is argued as the ultimate combination of connecting with fans and giving them a reason to buy, where recorded music now effectively sells live music. As additional touring to recoup the losses from poor sales of recorded music is not economically or environmentally sustainable, future business models must adopt a more holistic, integrated approach through multi-disciplinary research; where more qualitative research could prove particularly useful. As Chesbrough (2010, p. 362) notes: 'Business model innovation is vital, yet very difficult... the barriers to change are real. [Model] experiments will fail, but [if] they inform new approaches and understanding, this is to be expected - even encouraged'.

Looking ahead to potential models of music distribution, Ogden et al.'s (2011, p. 125) comprehensive review of music marketing draws together some salient threads discussed in the present review; adopting a positive outlook for the future:

Despite a thousand years of marketing by third parties, it seems that music marketing is moving back to its roots. Artists are able to perform as their own record labels. Although uncertain what channels will be popular in years to come, it will most likely involve technology and a greater degree of personalization and value creation on the part of the artists.

\section{ACKNOWLEDGMENTS}

Thanks go to Dr. Laura Mitchell and Professor Raymond MacDonald for their feedback on earlier drafts of this article along with the encouragement received from attendees at the UK conferences where an earlier version of this article was presented.

\section{NOTES}

[1] Steven Caldwell Brown, Psychology and Allied Health Sciences, Glasgow Caledonian University, Cowcaddens Road, Glasgow, G4 0BA, UK e-mail: steven.brown@gcu.ac.uk.

[2] Working link to the presentation is available at http://www.youtube.com/watch?v=NjuolpuB1lg.

[3] Headings and sub-headings contain references to Nine Inch Nails lyrics and song titles. 
[4] Whilst Trent Reznor is Nine Inch Nails, they are referred to independently in the interests of distinguishing a person from a brand.

[5] Masnick coined the phrase in a 2005 blog entry as a response to the singer's attempts to censor images of her home appearing online - with surprising results. Cacciottolo (2012) reports 420,000 visits to the website hosting the images in a month, further to her legal action making headline news globally. Prior to this, images of her house were only downloaded 6 times - including twice by her lawyers. The news article cited above includes a high-profile example of this effect in the world of music piracy (where record amounts of traffic to The Pirate Bay were noted, after 5 UK ISP's were ordered to block access to the copyright-infringing website). The phrase is often used to account for the counter-intuitive outcome of having drawn attention to something you wish to suppress.

\section{REFERENCES}

Amos, T. \& Powers, A. (2005). Piece by Piece. New York: Broadway.

Benenson, F. (2009). NIN's CC-Licensed Best-Selling MP3 Album.

http://creativecommons.org/weblog/entry/11947

Bhattacharjee, S., Gopal, R.D., \& Sanders, G.L. (2003). Digital music and online sharing: Software Piracy 2.0? Communications of the ACM, Vol. 46, No. 7, pp. 107-111.

Bruno, A. (2007). Reznor sounds off on pricing.

http://www.azcentral.com/ent/music/articles/0515reznor0515-ON.html

Cacciottolo, M. (2012). The Streisand Effect: When censorship backfires. http://www.bbc.co.uk/news/uk$\underline{18458567}$

Cheng, H.K., Sims, R.R., \& Teegen, H. (1997). To purchase or to pirate software: An empirical study. Journal of Management Information Systems, Vol. 13, No. 440, pp. 49-60.

Chesbrough, H. (2010). Business Model Innovation: Opportunities and Barriers. Long Range Planning, Vol. 43, pp. 354-363.

Chiu, H., Lin, Y., Lee, M., Nieh, M., \& Chen, H. (2008). How to discourage online music piracy. International Journal of Management and Enterprise Development, Vol. 5, No. 6, pp. 723-738.

Cockrill, A., Sullivan, M., \& Norbury, H.L. (2011). Music consumption: Lifestyle choice or addiction. Journal of Retailing and Consumer Services, Vol. 18, pp. 160-166.

Colothan, S. (2007). Sigur Ros Praise Radiohead's 'In Rainbows'. http://www.gigwise.com/news/38292/Sigur-Ros-Praise-Radioheads-In-Rainbows

Conner, K.R., \& Rummelt, R.P. (1991). Software piracy: An analysis of protection strategies. Management Science, Vol. 37, pp. 125-139.

Connolly, M., \& Krueger, A.B. (2006). Chapter 20 Rockonomics: The Economics of Popular Music. Handbook on the Economics of Art and Culture, Vol. 1, pp. 667-719.

Cruz, A. (2008). SN\&R's exclusive Trent Reznor interview. http://www.newsreview.com/sacramento/content?oid=886178 
Curien, N., \& Moreau, F. (2009). The music industry in the digital era: Toward new contracts. Journal of Media Economics, Vol. 22, pp. 102-113.

David, M. (2010). Peer to Peer and the Music Industry. London: Sage.

Dilmperi, A., King, T., \& Dennis, C. (2011). Pirates of the web: The curse of illegal downloading. Journal of Retailing and Consumer Services, Vol. 18, pp. 132-140.

Dubber, A. (2011). Monkey on the Roof: Researching creative practice, music consumption, social change and the online environment. Creative Industries Journal, Vol. 4, No.1, pp. 19-31.

Farrugia, R., \& Gobatto, N. (2010). Shopping for Legs and Boots: Tori Amos's original bootlegs, fandom, and subcultural capital. Popular Music and Society, Vol. 33, No. 3, pp. 357-375.

Forde, E. (2011). David Guetta targets fanbase, not pirates. http://www.musicweek.com/story.asp?sectioncode $=1 \&$ storycode $=1044047$

Goldberg, G. (2009). Own nothing, have everything: Peer-to-peer networks and the new cultural economy. Ph.D dissertation. City University of New York.

Gopal, R.D., \& Sanders, G.L. (1998). International software piracy: Analysis of key issues and impacts. Information Systems Research, Vol. 9, No. 4, pp. 380-397.

Green, C. (2008). Radiohead sales show fans' loyalty to illegal sites. http://www.independent.co.uk/artsentertainment/music/news/radiohead-sales-show-fans-loyalty-to-illegal-sites-884239.html

Harbi, S.E., Grolleau, G. \& Bekir, I. (in press). Substituting piracy with a pay-what-you-want option: does it make sense? European Journal of Law and Economics.

Holt, A. (2010). The economy of live music in the digital age. European Journal of Cultural Studies, Vol. 13, No. 2, pp. 243-261.

Idolator (2008). Trent Reznor On "NiggyTardust" Sales: Thanks For Being Jerks, Internet. http://idolator.com/340535/trent-reznor-on-niggy-tardust-sales-thanks-for-being-jerks-internet

Ivaldi, A., \& O'Neill, S.A. (2008). Adolescents' musical role models: whom do they admire and why? Psychology of Music, Vol. 36, No. 4, pp. 395-415.

Kim, J-Y., Natter, M., \& Spann, M. (2009). Pay-what-you-want - A new participative pricing mechanism. Journal of Marketing, Vol. 73, No. 1, pp. 44-58.

Leanord, M. (2009). Robert Smith blasts “idiot” Radiohead. http://www.musicradar.com/news/guitars/robert-smith-blasts-idiot-radiohead-197836

Lee, G.D., \& Low, R. (2004). Internet pirates: generational attitudes towards intellectual property online. Paper presented at the ANZMAC Conference, Wellington, Monash University.

Malin, J., \& Flowers, J.B. (2009). Adolescent self-control and music and movie piracy. Computers in Human Behaviour, Vol. 25, pp. 718-722.

Masnick, M. (2005). Since When Is It Illegal To Just Mention A Trademark Online? http://www.techdirt.com/articles/20050105/0132239.shtml 
Masnick, M. (2009). How Trent Reznor and Nine Inch Nails Represent the Future of the Music Business. Presentation given at 2009 Midem and Midemnet, Cannes, France.

McIntyre, C. (2011). News from somewhere: The poetics of Baby Boomer and Generation Y music consumers in tracking a retail revolution. Journal of Retailing and Consumer Services, Vol. 18, No. 2, pp. $141-151$.

Menger, K. (1871). Principles of Economics. New York: New York University Press.

Mortimer, J., Nosko, C., \& Sorensen, A. (2010). Supply Responses to Digital Distribution: Recorded Music and Live Performances (Working Paper No.16507).

Moses, A. (2007). Nails frontman urges fans to steal music. http://www.smh.com.au/news/web/steal-awaysteal-steal-and-steal-some-more/2007/09/18/1189881482912.html

Naghavi, A.J., \& Shulze G.G. (2001). Bootlegging in the music industry: A note. European Journal of Law and Economics, Vol. 12, No. 1, pp. 57-72.

North, A., \& Hargreaves, D. (1995). Eminence in pop music. Popular music and society, Vol. 19, pp. 4166.

North, A., \& Hargreaves, D. (2002). Age variations in judgments of 'great' art works. British Journal of Psychology, Vol. 933, pp. 397-405.

North. A., \& Hargreaves, D. (2008). The Social and Applied Psychology of Music. Oxford: Oxford University Press.

Nutall, P., Arnold, S., Carless, L., Crockford, L., Finnamore, K., Frazier, R., \& Hill, A. (2011). Understanding music consumption through a tribal lens. Journal of Retail and Consumer Services, Vol. 18, pp. 152-159.

Ogden, J.R., Ogden, D.T., \& Long, K. (2011). Music marketing: A history and landscape. Journal of Retailing and Consumer Services, Vol. 18, pp. 120-125.

Piolatto, A., \& Schuett, F. (2012). Music piracy: A case of "The Rich Get Rich and the Poorer Get Poorer". Information Economics and Policy, Vol. 24, No.1, pp. 30-39.

Rees, P. (1999). Interview with Trent Reznor. http://www.theninhotline.net/archives/articles/xint30.shtml

Regner, T., \& Barria, J.A. (2009). Do consumers pay voluntarily? The case of online music. Journal of Economic Behavior and Organization, Vol. 71, pp. 395-406.

Regner, T., Barria, J.A., Pitt, J., \& Neville, B. (2009). An artist life-cycle model for digital media content: Strategies for the Light Web and the Dark Web. Electronic Commerce Research And Applications, Vol. 8, pp. 334-342.

Regner, T. (2010). Why Consumers Pay Voluntarily: Evidence from Online Music. Jena Economic Research Papers 2010-081.

Ryan, K. (2009). Trent Reznor of Nine Inch Nails. http://www.avclub.com/articles/trent-reznor-of-nineinch-nails,32806 
Saarikallio, S., \& Erkkila, J. (2007). The role of music in adolescents' mood regulation. Psychology of Music, Vol. 35, No. 1, pp., 88-109.

Shultz, M.F. (2006). Fear and Norms And Rock \& Roll: What Jambands Can Teach Us About Persuading People To Obey Copyright Law. Berkeley Technology Law Journal, Vol. 21, pp. 651-728.

Smith, C.L. (2011). Will Radiohead's The King of Limbs save the music industry? http:/www.guardian.co.uk/music/musicblog/2011/feb/14/radiohead-king-limbs

This One Is On Us (2010). This One Is On Us - Mission Statement. http://thisoneisonus.org/mission.html

Wang, C., Chen, C., Yang, S., \& Farn, C. (2009). Pirate or Buy? The Moderating Effect of Idolatry. Journal of Business Ethics, Vol. 90, No. 1, pp. 81-93.

Wikstrom, P. (2009). The Music Industry: Music in the Cloud. Cambridge: Polity Press. 